\title{
SASKATCHEWAN BIRD SPECIES WHICH INCREASED WITH SETTLEMENT
}

\section{STUART HOUSTON and MARY I. HOUSTON, 863 University Drive, Saskatoon, SK S7N 0J8}

In the September 1944 issue of the Blue Jay, editor Isabel M. Priestly asked on behalf of the United States Fish \& Wildlife Service for information on Mourning Dove numbers, which appeared to be dropping in the United States. Her own observations were contrary to the trend south of the border, for Mourning Doves had become more common around Yorkton between the 1920s and 1944. In the December 1944 issue, the final one she edited (with her obituary notice added in at the time of mailing), she quoted Maurice Street as saying: "Mourning Doves have probably increased more in the Nipawin district than any other species with the exception of the Barn Swallow."

If the Barn Swallow increased the most, and the Mourning Dove increased second most, we may ask which other Saskatchewan species have adapted well to farms and towns and have increased in numbers. In attempting to answer this question we shall review the evidence, often scattered and fragmentary, for seven species which seem to have thrived with human presence: Mourning Dove, Tree Swallow, Barn Swallow, American Crow, Mountain Bluebird, American Robin, Red-winged Blackbird.

Five of the seven species, the Mourning Dove, Tree Swallow, Barn Swallow, American Crow and Mountain Bluebird, were initially quite rare across the southern prairies. The dove and crow have increased be- cause more food is available around farms than in unsettled prairie, and aspen bluffs now provide nest sites. Both the Tree Swallow and Mountain Bluebird are nest-site dependent and have responded to the widespread appearance of bird boxes on fence posts. The Barn Swallow found suitable nesting sites as soon as farms and buildings appeared. The American Robin had few nest sites on the treeless plains, regularly swept by prairie fires, but increased as trees grew up, particularly on farmsteads and in towns and villages. The Redwinged Blackbird was always common, so it is difficult to ascertain whether its numbers rose in the present century, but presumably they did in response to increased food supplies on its wintering grounds in the southern United States. Although evidence for all these species is largely anecdotal, rarely numerical and occasionally conflicting, we think general conclusions can nonetheless be reached.

In addition to the seven species which we discuss in detail, major population increases have been experienced by the Western Kingbird, which spread across the plains only after trees grew to $6 \mathrm{~m}$ in height and by the Black-billed Magpie, which returned after its range had been reduced to the Cypress Hills coincident with the disappearance of the bison. Changes in the range and numbers of these two species have been pub. lished previously. ${ }^{18,20}$ 
All localities mentioned are within Saskatchewan, unless specified.

Mourning Dove The Mourning Dove, initially restricted to river valleys, was already present at Fort Qu'Appelle in $1885 .{ }^{39}$ Macoun observed in 1894 that the river valley at Medicine Hat [Alberta] was the only site at which it was numerous between Manitoba and the Rocky Mountains. ${ }^{26}$ Its increase and spread are well documented. ${ }^{21,25,37}$ At $\mathrm{Ni}$ pawin this was the second-most-rapidly increasing species, having been quite rare until about $1935 .{ }^{38}$ It increased noticeably at Somme between 1972 and $1992 .^{15}$

Tree Swallow Coues found no Tree Swallows west of Pembina in 1873 and $1874^{6}$ and this species remained rare when settlers arrived on open prairie. At Crane Lake, on 3 June 1893, Raine noted that "Several Tree Swallows had nests in holes in the largest decayed trees in the bluff, so I collected a few clutches." ${ }^{34}$ In 1894, Spreadborough saw only two at Crane Lake. ${ }^{26}$ In 1932, Todd, in the Elbow-Davidson area, said "Tree Swallows were confined to the vicinity of houses and tree-growth." The only nest Todd located was in a telephone pole north of Raymore. ${ }^{40}$ As late as 1948, Godfrey's National Museum of Canada collecting party of four had only a single signting at Maple Creek, 4 June-14 July. ${ }^{11}$ In striking contrast, Tree Swallows were always present in parkland areas north of Fort Carlton. In the 1820s Richardson reported that "this neat and handsome swallow frequents the woody districts up to the sixtieth parallel, making its nest in hollow trees, of dry grass and feathers."22 Yet, as late as 1939 , it was rarely seen at Emma Lake, where a single pair nested in a bird box. ${ }^{28}$
On the plains, settlement brought more trees, telephone poles and fence posts with holes dug by Northern Flickers, as well as mail boxes, twine boxes on binders, and crevices in buildings. These made excellent nesting sites for the Tree Swallow; its numbers increased rapidly. ${ }^{23}$ Smith summarized this well: "Formerly a transient over much of the southern plains, it has recently established itself as a breeding bird in many districts. Its expansion has been aided by humans through the quelling of prairie fires, which has allowed for southward spread of aspen bluffs. Tree Swallows in all settled regions have also benefitted by the provision of nest boxes." ${ }^{37}$

\section{Barn Swallow John Richardson} found it "Common [in] summer ... North to $68^{\circ}$; migratory ... In the furcountries, where the habitations of man are few and far between, it inhabits caves, particularly in the limestone rocks; and it also frequents the outhouses at the trading-posts." ${ }^{22}$ Across the Northern Great Plains, buildings were few and far between for a century and a half. Two references show that the Barn Swallow was absent or rare in northern North Dakota and Montana, just south of the 49th parallel. In 1869, J.G. Cooper reported: "I saw no sign of its nests about the trading posts [Fort Union] where the Cliff Swallow has full possession of every available position for a nest." ${ }^{5}$ Coues, in 1873, listed it as a "very rare summer resident along the Mouse [Souris] River and various other points along the line," noting that "eligible breedingplaces ... being few and far between ... it is correspondingly uncommon." Coues found one small colony nesting on a cutbank on a small stream west of the Sweetgrass Hills in northern Montana in $1874 . .^{6}$ Similarly it was absent or rare in Manitoba. 


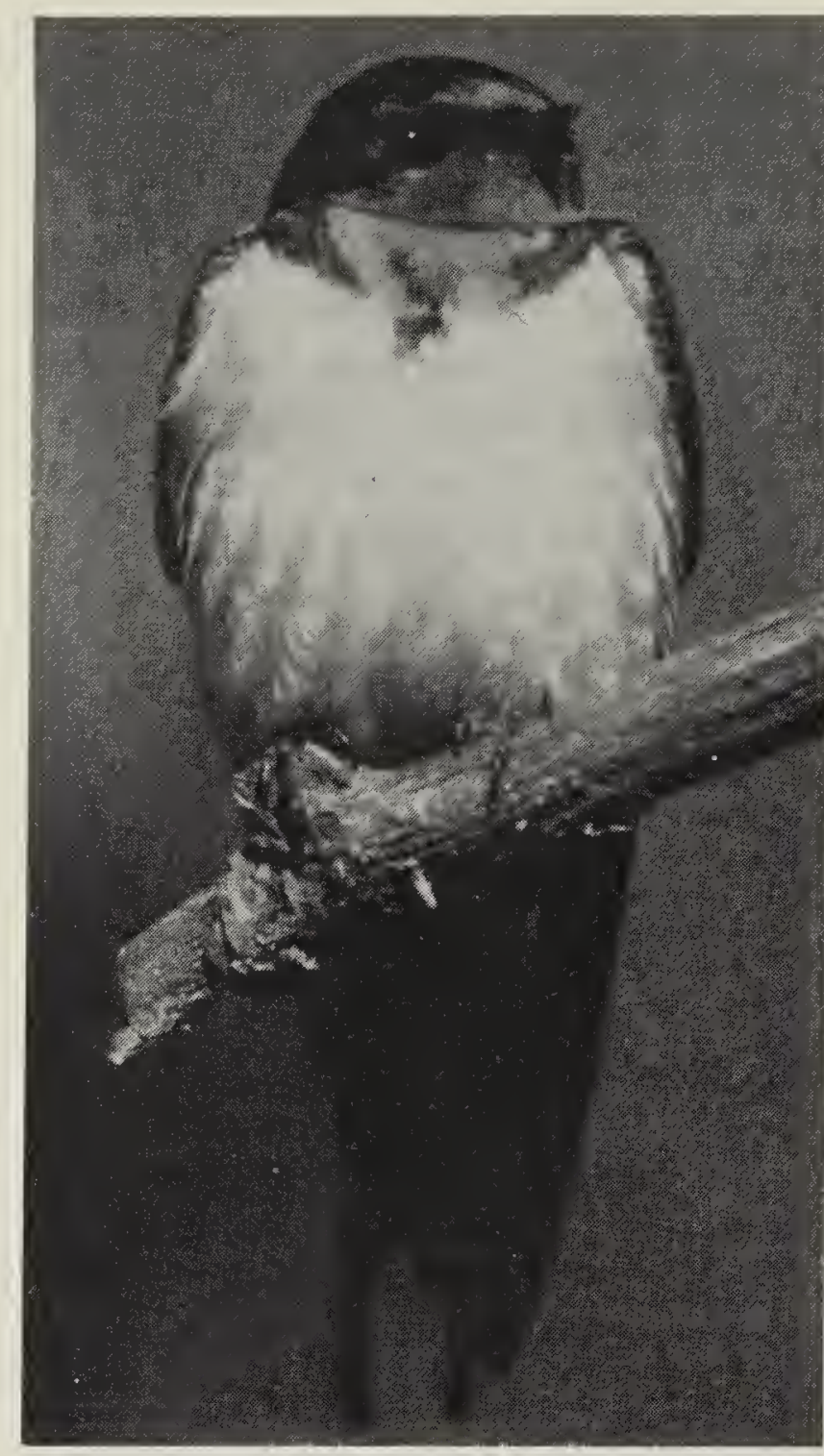

Barn Swallow

Wayne Lynch

Hine, at Winnipeg, Manitoba, listed it as an "accidental visitant; rare," and Nash said it "does not occur near Portage la Prairie or Winnipeg."39 Seton himself said it was merely a "rare spring visitant" at Carberry, 1882." 39 Guernsey, at Fort Qu'Appelle, noted it as a "Summer resident; breeds; arrives about May 20 "39 but it seems to have been uncommon there if none were seen until 20 May.

After buildings and bridges were erected along the new railway, it took up to ten years for Barn Swallows to adapt to these structures. At Rush Lake, Walter Raine found a nest attached to a cowshed on 25 May $1893,{ }^{34}$ and by 1894 Spreadborough noted "many pairs ... breeding in the farm buildings at Crane Lake." ${ }^{26}$ At Calgary, Alberta in 1895, J.E. Houseman reported: "Barn Swallows are scarce. I found only one nest ... underneath a small bridge."16 When Frank Baines settled west of Saltcoats in 1883, there were no Barn Swallows; they did not appear until about $1900 .^{17}$ By $1905-06$ this species was "fairly common about the ranches" near Maple Creek. ${ }^{2}$ Several pairs were nesting under a bridge at Quill Lake in 1909. ${ }^{10}$ Near Camrose, Alberta, as late as 1931, Frank Farley had never seen more than five together! ${ }^{9}$

Not one was seen by Congdon in the Prince Albert-Kinistino-Wakaw area in $1902,{ }^{4}$ nor at Sheho until a pair nested in a deserted house about $1917 .{ }^{31}$ Even as late as 1922 , only one was seen at Last Mountain and Old Wives lakes, by C.G. Harrold. ${ }^{14}$ As noted above, it "increased immensely" at Nipawin between 1930 and 1943. It first appeared in the Somme area about $1940 .^{15}$ Furniss found it a scarce summer resident and found no nests near Prince Albert, 1920-1943. ${ }^{22}$ In 1932 Todd found only "a few" at Davidson and Last Mountain Lake. ${ }^{40}$ Now Roy says, "with the possible exception of the House Sparrow and robin ... they are the best known bird in farmyard and village." 35 What a change this represents!

American Crow The dramatic increase of this species, which surely must rank in the top three, has been covered in an earlier paper. ${ }^{18} \mathrm{We}$ wish to corroborate those observations by demonstrating that the same increase took place in Manitoba and Alberta.

Hamilton Laing's father "told him that in 1870 only a few crows had hung around the first Kildonan Scotch settlement [north of Winnipeg, Manitoba] where the grainfields attracted them. With the development of the Clearsprings 
settlement [near present Steinbach] and the Mennonite fields westward, the crow soon took possession of the country."25 B.J. Hales made similar observations $160 \mathrm{~km}$ farther west at Brandon: "Before the settlement of the prairies crows were not plentiful. ... the early settlers all agree that crows were formerly scarce on the prairie. With the coming of man his food supply increased, and the crow increased in numbers out of all proportion to other birds." ${ }^{13}$

At Camrose, Alberta, Frank L. Farley made similar observations concerning "the extraordinary increase in the number of crows. In 1892 , the year of my arrival in Alberta, I did not record a single crow ... Only the odd pair was seen during the next few years, and it was not until the beginning of the present century that their numbers showed any material increase. By 1910 there were evidences that crows would shortly become a menace to our water-fowl ... The increase has been phenomenal."

Mountain Bluebird This species was rare, even in migration, prior to settlement. Not one was seen by Richardson or Drummond on the North Saskatchewan River in the 1820 s, by Blakiston in 1858 , or by R.R. MacFarlane at Cumberland House in $1890 .^{22}$ John Macoun saw his first on his early western trips beginning in 1872, but not until 1895 did he find nests in the badlands south of Wood Mountain on 14 June, and Frenchman River, 21 June. ${ }^{19,26}$ The first Manitoba record was 8 October 1896, when two were seen near Brandon and one was collected by E.H. Patterson. ${ }^{1}$ At about the same time Norman Criddle found them nesting in hollow oak stumps in the Carberry sandhills southeast of Brandon, although as late as 1904 not a single migrant had been seen at the Criddle farm itself, near Treesbank. Mountain Bluebirds began nesting there about 1912 and replaced the Eastern Bluebird by $1925^{7,8}$ In Saskatchewan, even in the favourable habitat of the Cypress Hills, Mountain Bluebirds were still uncommon when Laurence Potter arrived to ranch there in 1901, though they increased perceptibly between 1911 and $1923 .{ }^{33}$

By 1923 Mountain Bluebirds had spread as far east as Regina and as far north as Edam. ${ }^{27}$ They did not reach Saltcoats and Yorkton until 1930, ${ }^{17}$ Dafoe in 1932 (Todd's only sighting in the Simpson-DavidsonElbow area), ${ }^{40}$ and Sheho, even in migration, until $1938 .^{31}$ At Nipawin, Street's first sighting was 8 May 1932, and his first nesting ${ }^{25}$ May 1939. By 1958, 14 nests were known and another 11 not confirmed at Nipawin. ${ }^{22}$ In the Qu'Appelle Valley, Callin said they "were regular and fairly common only since the 1940s." 3

Mountain Bluebirds continue to nest in natural cavities on badland cliff faces in river valleys of southern Saskatchewan and Alberta, but the greater part of their population now use artificial nestboxes.

American Robin Macoun, though finding the American Robin common at most sites, nevertheless said "It is essentially a bird of civilization." 26 There is some evidence that this species increased in numbers on the formerly open plains as domestic trees slowly grew in villages and on farms. At Pembina, North Dakota, Coues found it "in abundance ... breeding in the wooded river-bottom" but said that "Further westward the species seems to occur chiefly during the migrations, as most of the 


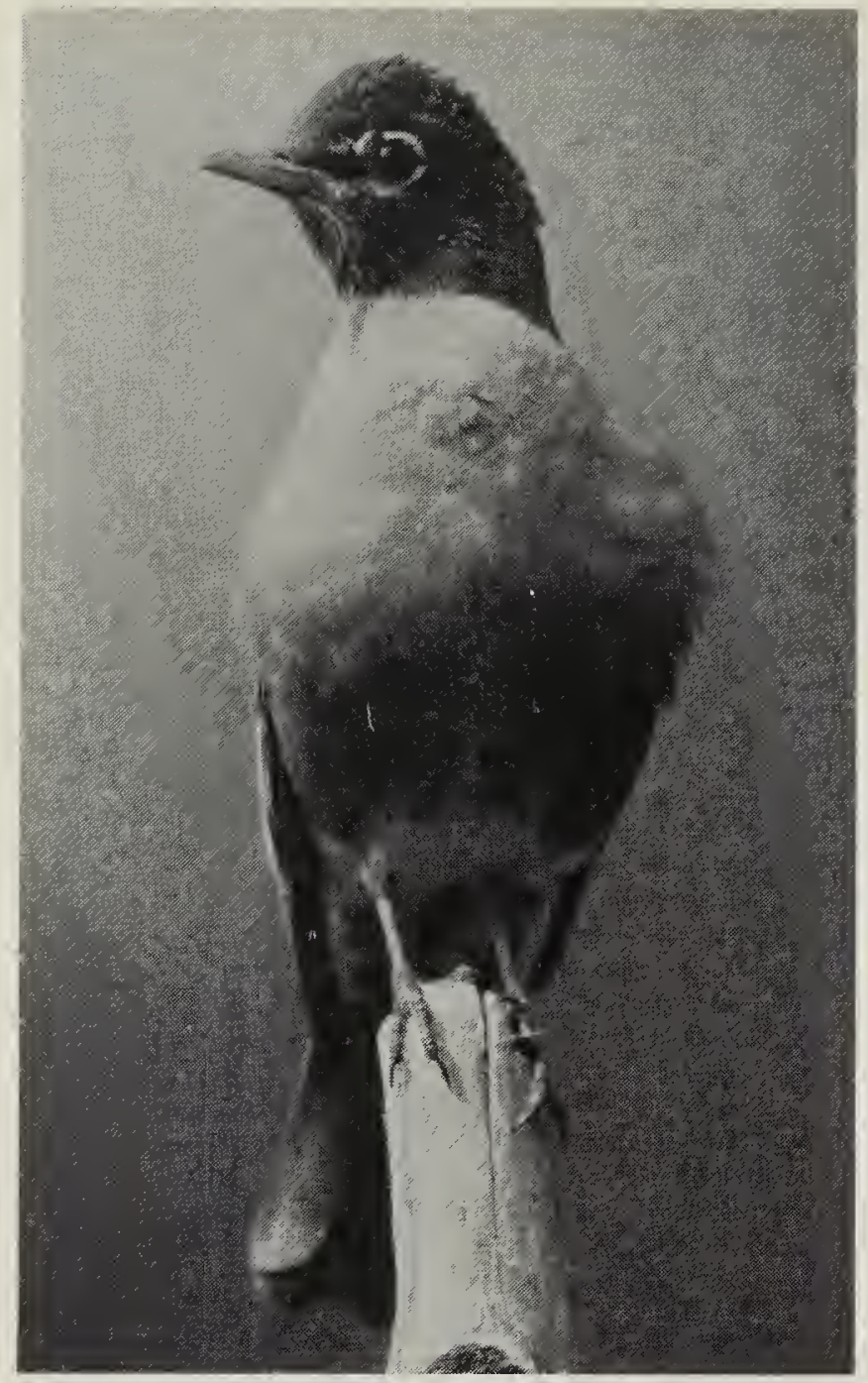

American Robin

Wayne Lynch

country is unsuited to its wants." Walter Raine saw a robin on 8 June 1893 at the foot of Tunnel Mountain at Banff, forgetting for the moment the one nest he had found at Moose Jaw on 7 June 1891, and remarked that it was a species "I never saw in Assiniboia." ${ }^{34}$ During a collecting trip in southern Saskatchewan, 26 April29 May 1922, only one pair was seen by C.G. Harrold, in a village 16 $\mathrm{km}$ from Old Wives Lake. ${ }^{14}$ At Camrose, Alberta, Farley was one of the few who documented the widespread increase in numbers: "Robins are much more plentiful now than they were when the country was first settled. During the entire summer of 1892 I did not see as many robins as I now see in a single day. It appears to enjoy the association of man." At Sheho, the robin became common and "semi-domesticated" with settlement. ${ }^{34}$ It began nesting on the Belcher farm south of Dilke only about 1948 , twenty years after planting of the farm shelterbelt. In 1982, Ann Jeffries reported from near Otter Lake an example of robins moving in to take advantage of new habitat when a garden was carved out of the northern forest. ${ }^{24}$ Since trees have grown up in every city, town and village in Saskatchewan, the robin is now highly visible and audible to all.

Red-winged Blackbird In 1984 Nero reported that the Red-winged Blackbird was "probably the most abundant bird species in North America." ${ }^{30}$ This probably was not true one or two centuries earlier, but surprisingly little documentation is available to tell when or even if big increases occurred. The arrival dates given for Fort Carlton in the 1820s, "beginning of May" by Richardson and 4 May 1858 by Blakiston, is suggestive but inconclusive evidence for smaller populations then than now. ${ }^{22}$ In 1873, Coues reported it was "certainly not a conspicuous feature of the region" along the 49th parallel, west of the Red River, noting that it was the least common blackbird. ${ }^{6}$ In 1893, Seton reported that it had "increased remarkably within the last ten years. ${ }^{36}$ It was already common in the Qu'Appelle Valley, in 1885 to 1895 , or as Arnold claimed, in "countless numbers." Absent on the north shore of Lake Athabasca in 1920 , it was common there in $1960 .^{29}$ Its increase in Texas dated "Since rice growing became important on the upper Texas coast beginning in the early years of the twentieth century..." ${ }^{32}$ As another bit of evidence that this increase was continent-wide, Graber and Graber reported that the population density increased greatly in the Midwest during the first half of the twentieth century. ${ }^{12}$

Other species, resident in parkland, spread south to occupy the farm shelter belts and the aspen 
bluffs as they appeared in fields. The increase in numbers of these species was simply an adaptation to availability of trees. The Chipping Sparrow was "quite rare" in southern Manitoba $^{39}$ and "uncommon" near Camrose, Alberta; ${ }^{9}$ it took longer than most other species to accommodate to trees and did not appear at the Beckie farm at Bladworth until the 1960s. ${ }^{35}$ The Baltimore Oriole similarly took advantage of appropriate habitat unavailable when the plains were almost treeless, and today, on the previously open plains, it is "one of the most characteristic and welcome birds of village and farmstead." ${ }^{\text {35 }}$ The Common Grackle, as Roy says, "is now almost exclusively identified with human habitation, most of them nesting in towns and villages, at farmsteads, and at lake resorts. ... they did not nest at the Jordheim farm southwest of Kyle until the late 1970s." ${ }^{35}$

Although human presence has had positive effects on the species mentioned, the negative effects on many others require ongoing, vigilant scrutiny.

1. ATKINSON, G.E. 1904. Rare bird records of Manitoba. Hist. Sci. Soc. Man. Trans. 65.

2. BENT, A.C. 1907. 1908. Summer birds of southwestern Saskatchewan. The Auk 24:407-430 and 25:25-35.

3. CALLIN, E.M. 1980. Birds of the Qu'Appelle, 1857-1979. Sask. Nat. Hist. Soc. Spec. Publ. 13.

4. CONGDON, R.T. 1903. Saskatchewan birds. Trans. Wisc. Acad. 14:569620.

5. COOPER, J.G. 1869. The fauna of Montana territory, Birds, part 2. Am. Nat. 3:31-35.

6. COUES, E. 1878. Field-notes on birds observed in Dakota and Montana along the 49th parallel during the seasons of 1873 and 1874, Bull. U.S. Geol. and Geog. Survey Terr. 4:545661.
7. CRIDDLE, N. 1904. The Mountain Bluebird in Manitoba. Ottawa Nat. 18:85-86.

8. - 1927. Habits of the Mountain Bluebird in Manitoba. Can. Field-Nat. 41:40-44.

9. FARLEY, F.M. 1932. Birds of the Battle River region of central Alberta. Institute of Applied Art, Edmonton.

10. FERRY. J.F. 1910. Birds observed in Saskatchewan during the summer of 1909. Auk 27:185-204.

11. GODFREY, W.E. 1950. Birds of the Cypress Hills and Flotten Lake regions, Saskatchewan. Nat. Mus. Canada Bull. 120.

12. GRABER, R.R. and J.W. GRABER. 1963. A comparative study of bird populations in Illinois, 1906-1909 and 1956-1958. III. Nat. Hist. Surv. Bull. 28:383-528.

13. HALES, B.J. 1927. Prairie birds. Macmillan, Toronto.

14. HARROLD, C.G. 1933. Notes on the birds found at Lake Johnston and Last Mountain Lake, Saskatchewan, during April and May 1922. Wilson Bull. 45:16-26.

15. HOOPER, D.F. 1992. Birds of eastcentral Saskatchewan. Sask. Nat. Hist. Soc. Spec. Publ. 18.

16. HOUSEMAN, J.E. 1895. North west notes for 1894. Oologist 12:8-11.

17. HOUSTON, C.S. 1949. The birds of the Yorkton district, Saskatchewan. Can. Field-Nat. 63:215-241.

18. - 1977. Changing patterns of Corvidae on the prairies. Blue Jay 35:149-156.

19. 1977 . The prairie bluebird trail. Nature Canada 6(2):3-9.

20. - 1979. The spread of the Western Kingbird across the prairies. Blue Jay 37:149-157.

21. 1986 . Mourning Dove numbers explode on the Canadian prairies. Am. Birds 40:52-54.

22. HOUSTON, C.S. and M.G. STREET. 1959. Birds of the Saskatchewan River, Carlton to Cumberland. Sask. Nat. Hist. Soc. Spec. Publ. 2. 
23. HOUSTON, M.I. and C.S. HOUSTON. 1988. Tree Swallow banding near Saskatoon, Saskatchewan. N. Am. Bird Bander 12:103-108.

24. JEFFRIES, A. 1983. Robins and humans. Blue Jay 41:62-63.

25. MACKIE, R. 1985. Hamilton Mack Laing: hunter-naturalist. Sono Nis Press, Victoria, B.C.

26. MACOUN, J. 1900. 1903. 1904. Catalogue of Canadian birds. S.E. Dawson, Ottawa.

27. MITCHELL, H.H. 1924. Birds of Saskatchewan. Can. Field-Nat. 38:101118.

28. MOWAT, F.M. Notes on the birds of Emma Lake, Saskatchewan. Can. Field-Nat. 61:105-115.

29. NERO, R.W. 1963. Birds of the Lake Athabasca region, Saskatchewan. Sask. Nat. Hist. Soc. Spec. Publ. 5:25

30. - 1984. Redwings. Smithsonian Institution Press, Washington.

31. NIVEN, W. 1973. The land, the birds, through 50 years in aspen parkland. Blue Jay 31:223-229.
32. OBERHOLSER, H.C. 1974. The bird life of Texas. University of Texas Press, Austin.

33. POTTER, L.B. 1923. Notes on birds in southwest Saskatchewan. Condor 25:102-103.

34. RAINE, W. 1894. Bird-nesting in northwest Canada. Nidiologist 1:67$71,117-120,130-133$.

35. ROY, J.F. 1996. Birds of the Elbow. Sask. Nat. Hist. Soc., Spec. Publ. 21.

36. SETON, E.T. 1908. Recent bird records for Manitoba. Auk 25:450-454.

37. SMITH, A.R. 1996. Atlas of Saskatchewan birds. Sask. Nat. Hist. Soc. Spec. Publ. 22

38. STREET, M.G. 1944. Mourning doves. Blue Jay 3:9.

39. THOMPSON, E.T. 1891. The birds of Manitoba. Proc. U.S. Nat. Mus. 13: 457-643.

40. TODD, W.E.C. 1947. Notes on the birds of southern Saskatchewan. Ann. Carnegie Mus. 30:383-421.

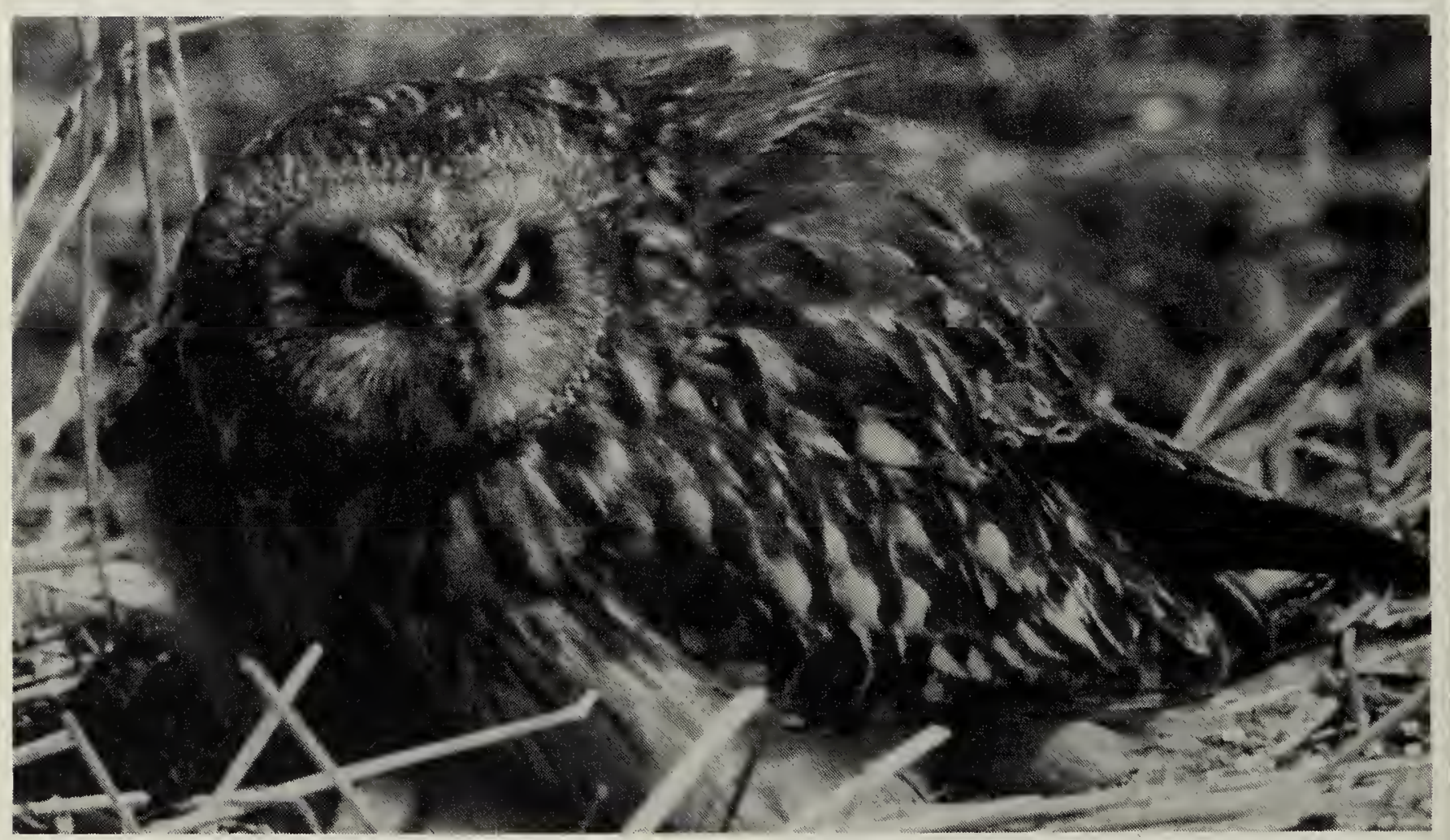

